\title{
On a collection of Reptiles from Kismayu.
}

\author{
By
}

EINAR LÖNNBERG and LARS GABRIEL ANDERSSON.

With one figure in the text.

Read May 28th 1913.

Some time ago the Swedish Missionary, Rev. TH. EngDAHL, kindly presented to the Nat. Hist. Museum, Stockholm, a collection of lizards and snakes from Kismayu and Mofi, near Juba river in the northeastern corner of British East Africa. This collection contains a number of quite interesting animals belonging to the typical Somali-fauna and also two new species of snakes.

\section{Lizards.}

Hemidactylus mabouia Mor. DE Jonnès.

6 specimens.

\section{H. turcicus LiN.}

2 specimens which are provided with resp. 8 and 7 lamellæ under the inner, and 10 under the median toe, thus more than in $H$. sinaitus and brookii. This locality appears to rather southern for this Gecko.

\section{H. ruspolii BLGR.}

14 specimens. 
Lygodactylus picturatus Peters.

4 specimens.

Varanus niloticus Lin.

1 young specimen.

Agamodon anguliceps Peters.

2 specimens from Mofi have four labials, three small anterior and a large posterior. The first is free from the nasal.

Latastia longicaudata Reuss.

12 specimens.

Mabuia brevicollis WIEgm.

1 specimen.

M. planifrons Peters.

7 specimens.

Lygosoma sundevallii Siтtн.

8 specimens.

Chamæleon dilepis Leach.

3 specimens.

Snakes.

Boodon lineatus Dum. \& Bibr.

4 specimens.

Lycophidium capense Sмiтн.

1 specimen.

Mehelya [Simocephalus] somaliensis n. sp.

Rostral nearly twice as broad as deep, just visible from above; internasals slightly broader than long, about two thirds the length of the præfrontals; frontal hardly as long as broad, 
almost as long as its distance from the rostral, longer than the præfrontals but much shorter than the parietals; loreal slightly longer than deep; one præ- and two postoculars, the præocular is, however, on one side semidivided, the lower portion being much the smaller; temporals $1+2$, the first widely separating the parietal from the fifth labial; seven upper labials, third and fourth entering the eye; five lower labials in contact with the anterior chinshields which are longer than the posterior. Scales strongly keeled, in 15 rows. The enlarged bicarinate scales of the median row are provided with a more or less continuous secondary keel on either side, and sometimes with a faint trace of another. The lateral scales show more or less pronounced traces of a secondary keel on either side in the shape of a series of small tubercles. The scales of the row next to the gastrosteges are enlarged, smooth on the lower, and with traces of a secondary keel on the upper half. The scales of next row are hardly broader than the scales of the other lateral rows. Ventrals 221, anal entire, subcaudals 62. Uniformly dark slate brown above, paler, greyish brown below with light edges to the gastrosteges, throat whitish.

This snake is evidently closely related to $M$. [S.] butleri BLGR. from the Bahr-el-Ghasal province, but the latter has the loreal deeper than long, three postoculars, the first temporal only narrowly separating the parietal and the fifth labial, and white basal spots on the scales etc.

M. [S.] unicolor BLGR. from the Kenia district has two superposed loreals, three postoculars, and the frontal only slightly shorter than the parietals.

M. [S.] chanleri Stejneger from the island Manda north of Lamu, Brit. E. Africa has three postoculars, the row of scales next to the gastrosteges with secondary keels on both sides, and the scales of the adjoining row with two secondary keels on the lower half. The vertebral row of scales has two secondary keels on either side. The scales in the second row from the gastrosteges have also quite another shape than in the new species being »scarcely longer than wide».

M. [S.] nyassce GTHR. from Nyassa land and Zanzibar has only one postocular, and only $171-178$ ventrals.

In a future most probably the present and several other »species» of this genus will prove to be only geographic sub- 
species of one and the same species, but for the present we are not able to express any definite opinion about which ought to be regarded as the main species. The differences recorded above have within this genus repeatedly been used as specific characteristics, and as we could not neglect these we had no other way out of the difficulties than to name this snake from Kismayu.

Philothamnus semivariegatus Sмгтн.

1 specimen.

\section{Chlorophis neglectus Peters.}

2 specimens. This locality appears to be the most northeastern for this species.

Dasypeltis scabra Lin.

1 specimen.

Tarbophis guentheri Anderson.

3 specimens.

Leptodira hotamboeia LAUR.

2 specimens.

Hemirhagerrhis kelleri BTTGR.

2 specimens.

Psammophis sibilans Lis.

2 specimens.

Psammophis biseriatus Peters.

1 specimen.

\section{Thelotornis kirtlandi HaLLOW.}

2 specimens. It appears rather strange to find this treesnake within the boundaries of the Somali-fauna. Probably it inhabits the trees fringing Juba river. 
LÖNNBERG AND ANDERSSON, REPTILES FROM KISMAYU.

\section{Dispholidus typus Smith.}

1 specimen.

\section{Brachyophis revoili Mocquard.}

2 specimens. These agree almost in every respect with MOCQUARD's original description of this very interesting snake. Our specimens have, however, only one postocular, and only one of the labials, viz. the fourth, enters the eye. Boulenger's description differs from MocQUARD's with regard to the labials, as he says that the second and third are in contact with the præfrontal, while in our specimens the third and fourth labials are in contact with the præfrontal which is in agreement with MocquarD's words. In a similar way BouLENGER's description indicates that the fifth and sixth labials are in contact with the parietal, while in our specimens it is the sixth and seventh, as MocquaRD also has said. Whether these latter differences are due to variation, or possibly to a misprint we cannot tell.

Our largest specimen measures $335 \mathrm{~mm}$, which is a little more than the length recorded by Mocquard, viz. $252 \mathrm{~mm}$.

\section{Aparallactus concolor Fischer.}

2 specimens.

Naja nigricollis REINH. var. pallida BLGR.

1 specimen.

Causus resimus Peters.

3 specimens.

\section{Atractaspis engdahli n. sp.}

Head very flat, depressed; snout broad and rounded. Portion of rostral visible from above measuring about a third its distance from the frontal; suture between the internasals slightly shorter than that between præfrontals; frontal a little broader than long, about equal to its distance from the end 
of the snout, much shorter than the parietals. Eye very small about equal in size to the nostril which is pierced between two nasals, the anterior of which is larger. One præ- and one postocular. Temporals $1+2$, the anterior situated below the postocular and wedged in between fourth and fifth labials; the upper posterior temporal in contact with the postocular (in one specimen very narrowly). Six upper labials, the fourth much the largest, in contact with the præocular, the eye and the postocular. First lower labials entirely separated by the symphysial being in contact with the large chin-shields; three
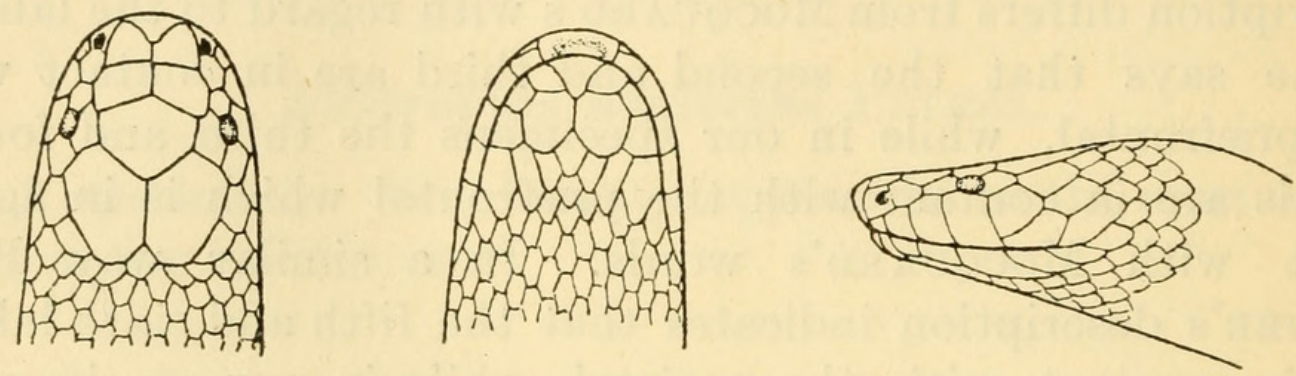

Fig. 1. Atractaspis engdahli n. sp. $2 / 1$ nat. size.

infralabials in contact with the chin-shields; fourth infralabial very large. Scales in 19 rows. Ventrals 224-232; anal divided; subcaudals in two rows forming 19-22 pairs. Tail especially in the largest specimen thick, and bluntly pointed in the younger. Uniform dark brown or black above, a little paler below.

Total length $415 \mathrm{~mm}$; tail $23 \mathrm{~mm}$.

This species is very easily recognized by its divided anal and subcaudals, six upper labials the fourth of which alone enters the eye, 19 rows of scales, the first pair of lower labials not meeting behind the symphysial etc. 


\section{$2 \mathrm{BHL}$ Biodiversity Heritage Library}

Lönnberg, Einar and Andersson, Lars Gabriel. 1913. "On a collection of reptiles from Kismayu." Arkiv för zoologi 8, 1-6.

https://doi.org/10.5962/bhl.part.1067.

View This Item Online: $\underline{\text { https://www.biodiversitylibrary.org/item/30180 }}$

DOI: https://doi.org/10.5962/bhl.part.1067

Permalink: https://www.biodiversitylibrary.org/partpdf/1067

\section{Holding Institution}

MBLWHOI Library

Sponsored by

MBLWHOI Library

\section{Copyright \& Reuse}

Copyright Status: NOT_IN_COPYRIGHT

This document was created from content at the Biodiversity Heritage Library, the world's largest open access digital library for biodiversity literature and archives. Visit BHL at https://www.biodiversitylibrary.org. 